Subscription in India and abroad Rupees 16 per annum. Post free. Payable in advance THE INDIAN

\title{
JOURNAL OF MEDICAL RESEARCH
}

Edited by THE DIRECTOR-GENERAL, INDIAN MEDICAL SERVICE, THE PUBLIC HEALTH COMMISSTONER WITH THE GOVERNMENT OF INDIA, and THE DIRECTOR, CENTRAL RESEARCH INSTITUTE, in collaboration with LEADING AUTHORITIES ON TROPICAL MEDICINE. The Indian Journal of Medical Research is published quarterly. Each number contains about 200 pages and is illustrated with Plates in Colour and Half-tone and with Diagrams and Charts, and is the only medium publishing the results of the best medical research work being carried on by leading scientific medical men in India and the East.

THACKER, SPINK \& CO. (P.O. BOX 54) LONDON ACENTS: W. Thacker \& Co., 2, Creed Lane, E.C. 4.

CALCUTTA

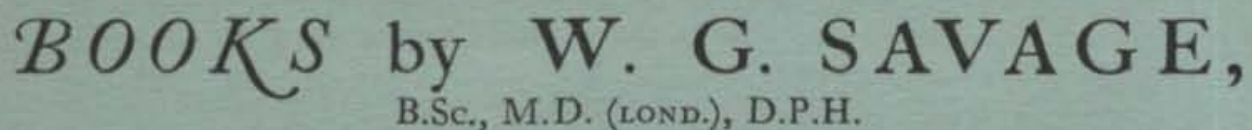

CANNED FOODS IN RELATION TO HEALTH. (Milroy Lectures, 1923.)

With 6 text-figures, 19 tables, and 1 chart. Demy 8 vo. $8 s 6 d$ net.

FOOD POISONING AND FOOD INFECTIONS. Demy 8 vo. $17^{s} 6 d$ net.

THE BACTERIOLOGICAL EXAMINATION OF FOOD AND WATER.

Second Edition. With 16 illustrations. Demy 8 vo. I 5 s net.

(Cambridge Public Health Series.)

CAMBRIDGE UNIVERSITY PRESS, Fetter Lane, London, E.C. 4

The Quarterly Journal of Medicine

Edited by

T. R. ELLIOTT

W. HALE-WHITE

A. E. GARROD

R. HUTCHISON

H. D. ROLLESTON

with the help of

J. Hill Abram

Byrom Bramwell

John Cowan

David Drummond

Francis R. Fraser

T. Wardrop Griffith
G. Lovell Gulland

Arthur J. Hall

Gordon Holmes

Arthur F. Hurst

J. A. Lindsay

H. Maclean

R. Stockman
George R. Murray

J. A. Nixon

R. W. Philip

E. P. Poulton

E. I. Spriggs

A. M. Stalker

SINGLE NUMBERS $10 \mathrm{~s}$. $6 \mathrm{~d}$. NET EACH

VOLUMES - - 45s. NET

SUBSCRIPTION - 35s. PER ANNUM 


\section{CONTENTS}

\section{(All rights reserved)}

EAstwoon, Arthur, Bacterial Virulence and Tmmunity

Fyme, G. Matrinew. Milk-borne Sonne Dysentery. (With 1 Graph) . 271

Ross, G. R. The Value of Non-specifie Agglutination in the Differentiation of the Genus Brucella . . . . . . . . .

Dudgeon, Leonard S. and Pulvertaft, R. J. V. On Slow Laetose Fermenting $B$. coli in Urinary and Intestinal Infections . . .

Greenwood, MAJor and Woods, HrLdA M. "Status Thymico-Lymphaticus" considered in the light of Recent Work on the Thymus .

Knnook, J. Paruane, Smin, J. and Taylor, J. S. The Newer Knowledge of Diphtheria and Scarlet Fever and its Application in Hospital Practice and in Community Immunisation. (With 2 Charts) . .

Hroks, E. P. The Value of Methods for the Differentiation of Bacilli of the Coli-aerogenes Group, when applied in Shanghai . . .

The Journal of Hygiene is issued as material accumulates. A volume containing four numbers is issued annually in paper covers at the following net prices:

Volumes I-III (1901-3), 17s, 6d.

Volumes IV - XVI(1904-18), exceptingVol.VI, no.4, Plague number. 25.

Volume XVII (1918). 318.

Volumes XVIII-XXV (1919-1926). 42s, each.

Quotations can be given for buckram binding cases and for binding subseribers' sets; also for bound copies of back volumes.

Papers for publication may be sent to Prof. Geo. H. F. Nutrall, F.R.S., Longfield, Madingley Road, Cambridge, or to the associate Editors. Other communications should be addressed to the University Press, Cambridge.

Papers forwarded to the Editors for publication are understood to be offered to The Journal of Hygiene alone, unless the contrary is stated.

Contributors receive fifty copies of their papers free. Additional copies may be had at cost price: these should be ordered when the final proof is returned.

The subseription price is $£ 2$. 28 , per volume (post-free), payable in advance; single numbers $12 s .6 \mathrm{~d}$. net. Subscriptions may be sent to any Bookseller, or to The Cambridge University Press, Fetter Lane, London, E.C. 4 .

The Cambridge University Press has appointed the University of Chicago Press agents for the sale of The Journal of Hygiene in the United States of America and has authorised them to charge the following prices: Subscription $\$ 10.00$ per volume; single numbers, $\$ 3.00$ each.

Plague Numbers, Vol. VI. no. 4 (out of print), Vol. VII. nos. 3 and 6 , and Vol. VIII. no. 2, Vol. X. no. 3, Price 6 s. net each.

A series of Plague Supplements has been issued; the first four of these contain Reports VI-IX on Plague Investigations in India. They are, in pagination, completely independent of the Journal although subscribers to the latter receive copies without extra cost. Price of Plague Supplements, 1. and ii. 7s. net each; iii. 10s. net; iv. and v. 7s, net each. Plague Supplements i, ii, iii can also be supplied bound in buckram, price 20 s. net. 